\title{
Eucalyptus Oil-Induced Seizures in Children: Case Reports and Review of the Literature
}

\author{
Sai Chandar Dudipala1, $\quad$ Prashanthi Mandapuram \\ ${ }^{1}$ Department of Pediatrics, Prathima Institute of Medical Sciences, \\ Karim Nagar, Telangana, India
}

\author{
Laxman Kumar $\mathrm{Ch}^{1}$
}

\begin{abstract}
Keywords

- antiepileptic drugs

- Eucalyptus oil

- seizures

- underrecognized
\end{abstract}

\begin{abstract}
Address for correspondence Sai Chandar Dudiapala, MD, Department of Pediatrics, Prathima Institute of Medical Sciences, Karim Nagar 505417, Telangana, India (e-mail: drsaichander@gmail.com).
\end{abstract}

\section{Introduction}

Eucalyptus oil (EO), is distilled volatile oil, extracted from the leaves of Eucalyptus trees. It is available in many over-the-counter (OTC) cough drops, lozenges, ointments, mouthwashes, and inhalants that are used orally, intranasally, or topically. ${ }^{1} \mathrm{EO}$ is used as a remedy for so many ailments like cold, rhinitis, abdominal pain, and toothache. ${ }^{2}$ However, EO has some adverse effects along with its beneficiary effects. In the literature, EO poisoning in children presented with various clinical syndromes., ${ }^{3,4}$ Among these, neurological manifestations like encephalopathy, seizure, and ataxia are mainly reported. These manifestations can occur with therapeutic dosage or overdose. In children, the first episode of seizures or breakthrough seizures can occur with EO ingestion. Unfortunately, clinicians did not focus and diagnosed EO-induced seizures (EOIS). Moreover, EOIS has not been familiar an entity, and clinicians hardly inquire the history of acquaintance to EO when approaching a patient with the first episode of seizures or breakthrough seizures. This is still considered as an underrecognized or misdiagnosed entity, resulting in an unessential hospitalization and investigations. Thus, it is an important observation for the clinicians to be aware of this condition that is still poorly described in the earlier literature. Therefore, in the current review, we attempted to report three case reports on children with the first episode of seizures occurring after EO ingestion i.e., EOIS.

\section{Patients and Methods}

We studied EOIS in three children who were evaluated at Prathima Institute of Medical Sciences, Karim Nagar, Telangana, India from March 2019 to Feb 2020. General, neurological examination, and laboratory tests were performed after the clinical diagnosis was suspected. All patients underwent serum electrolytes, electroencephalogram (EEG), and
DOI https://doi.org/ 10.1055/s-0040-1721199 ISSN 0976-3147. (c) 2021. Association for Helping Neurosurgical Sick People

This is an open access article published by Thieme under the terms of the Creative Commons Attribution-NonDerivative-NonCommercial-License, permitting copying and reproduction so long as the original work is given appropriate credit. Contents may not be used for commercial purposes, or adapted, remixed, transformed or built upon. (https://creativecommons.org/licenses/by-nc-nd/4.0/)

Thieme Medical and Scientific Publishers Pvt. Ltd., A-12, 2nd Floor, Sector 2, Noida-201301 UP, India 
magnetic resonance imaging (MRI) of the brain. We follow-up the patients at regular intervals up to 8 to 10 months duration.

\section{Case Reports}

\section{Patient 1}

A 3-year-old boy, a developmentally normal child, presented to the emergency department (ED) with the first episode of the generalized tonic-clonic seizure (GTCS) for 8 minutes. On arrival to ED, the child was actively convulsing, and the child was stabilized with oxygen inhalation, intravenous midazolam, and intravenous levetiracetam $(40 \mathrm{mg} / \mathrm{kg})$. After stabilization, he was drowsy, arousable with deep painful stimuli. He was afebrile, hemodynamically stable without any respiratory compromise. The child became conscious 40 minutes after admission to ED. He was only one child of a nonconsanguineous couple with normal antenatal and birth history. He had a seasonal cold on the same day and had taken 10 drops of EO with milk. He had vomiting 20 minutes after the ingestion of EO followed by a seizure. However, there was neither a past history of seizures nor a family history of epilepsy. There is no EO ingestion in the past. On laboratory evaluation, his complete blood count (CBC), serum electrolytes, blood glucose, liver function test, and creatinine were normal. His MRI brain was found to be normal. EEG showed moderate encephalopathy features. He was prescribed levetiracetam $100 \mathrm{mg}$ twice daily for 2 weeks. The child was followed up for 10 months and during this period he was found to be doing well with no recurrence of seizures.

\section{Patient 2}

A 4-year-old boy with a history of pain abdomen and ingestion of unknown amount of EO as a remedy for the first time presented to ED with one episode of GTCS seizure for 4 minutes followed by postictal drowsiness. He had this seizure 15 minutes after the ingestion of EO. On arrival to ED, he was stuporous, afebrile with a heart rate of 100 beat per minute and respiratory rate of 22 per minute with oxygen saturation $98 \%$ on room air. In ED, the child had one episode of vomiting and that contents of vomiting had the aroma of EO. He had a normal birth and developmental history. There was no history of seizures in the past or family history of seizures. Routine blood investigations (CBC, serum electrolytes, blood glucose, liver function tests, and creatinine) were normal. The child was treated with intravenous levetiracetam $20 \mathrm{mg} / \mathrm{kg}$. The child became conscious 45 minutes after hospitalization. His brain MRI and EEG was performed on the first and second day of seizure, respectively, and the reports were normal. He was prescribed with levetiracetam $150 \mathrm{mg}$ twice daily for 2 weeks as a treatment. Based on history, normal laboratory investigations, and normal neuroimaging, EOIS was considered. Up to 9 months of follow-up period, there was no recurrence of seizures.

\section{Patient 3}

A 7-year-old girl, a developmentally normal child, presented to the pediatric neurology clinic with a history of one episode of GTCS seizure for 2 minutes with the postictal period for
15 minutes. The child had a cold since morning, so she has taken $1 \mathrm{~mL}$ of EO with milk. This is the first-time child had taken EO. There was no history of seizures in the past or family. General and neurological examination was normal. Her routine blood investigations, EEG, and MRI brain were normal. The child was not advised for any antiepileptic medication. The child was advised to avoid EO. The child was followed up to 8 months, and she never had any seizures.

\section{Discussion}

EO, an aromatic constituent, distilled volatile oil extracted from the leaf of Eucalyptus, belongs to the family of Myrtaceae. The monoterpenes are the main group of constituents of EO, and the eucalyptol is a principal constituent, also known as cineole and 1,8-cineole, which must comprise at least $90 \%$ of the total contents. ${ }^{2.5}$ Most of the EO production worldwide comes from Eucalyptus globulus. ${ }^{6}$ The raw material storage condition, method of extraction, and purification can influence the composition of extracted oil.

EO is available commercially in many OTC cough drops, liniments, toothpaste, mouthwashes, and cold preparations. ${ }^{1}$ It is used widely all over the world for its extensive therapeutic properties. It is used to treat ailments like the common cold, sinusitis, toothache, headache, and pain abdomen in both children and adults. ${ }^{7}$ It can be used in various methods like ingestion, inhalation, or topical application. In the present reported observed cases, all three children received EO as oral ingestion.

Along with beneficiary effects, EO had some harmful effects on the human body. These harmful effects can occur with accidental overdose, unintentional intake, or sometimes with therapeutic dosages. Most of the EO preparations are available OTC and in variable concentrations. ${ }^{7}$ This causes the difficulty in deciding the therapeutic dosage of EO. The neurological manifestations of EO exposure are broad-spectrum, ranging from mild confusion to life threatening status epilepticus. These neurological features are focal and generalized seizures, status epilepticus, encephalopathy, and ataxia. ${ }^{8}$ EO has been identified to have epileptogenic properties, when they have been used for other therapeutic purposes. The exact underlying mechanism of epileptogenesis is still not well reported. In literature, some hypotheses were proposed by various studies. Dose-dependent and idiosyncratic fashion of EO is well established in animal studies. ${ }^{9}$ Furthermore, a loss of tissue sodium/potassium gradient leading to increased cellular hyperexcitability might be the reason for epileptogenesis in rat models. ${ }^{10,11}$

The temporal relation between the onset of seizures and ingestion of EO confirms the proconvulsive properties of EO. In children with EO toxicity, the main mode of exposure was ingestion and seizures developed after 30 to 240 minutes of ingestion. ${ }^{12}$ In the present reported cases, seizures developed within 20 to 40 minutes after exposure to EO. All the children took EO orally in varying amounts. Sometimes, seizures will develop within 2 to 5 minutes after inhalation of EO. Inhalation has faster action than the ingestion, because the 
inhaled volatile oils are identified to reach the brain directly and they stimulate the neurons. ${ }^{13}$

In 1898, the first case of EO poisoning was reported from Kerala, India. ${ }^{14}$ The second case was reported from UK in $1911 .{ }^{15}$ After that, more case studies were available in the literature (-Table 1). Flaman et al, reported EO ingestion causing seizures in children from 11 months to 3 years of age. The onset-time of seizure ranged from 10 to 120 minutes after EO ingestion. ${ }^{16}$ Two cases of status epilepticus have been reported in 6-year and 3-year-old boys after ingestion of 5 and $10 \mathrm{~mL}$ of EO, respectively. ${ }^{17}$ Seizures developed in 3.5 hours after dermal application of EO as head lice removal was reported. ${ }^{18} \mathrm{~A}$ study of 10 cases (five adults and five children) of EOIS was reported from India. ${ }^{13}$ The modes of exposure to EO in pediatric patients for this study were inhalation (three patients), intranasal instillation (one patient), and body massage (one patient). Two children were treated with levetiracetam for 2 to 4 weeks. In this

Table 1 Case reports of eucalyptus oil induced seizures

\begin{tabular}{|c|c|c|}
\hline Article & Case reports & Clinical findings \\
\hline $\begin{array}{l}\text { Patel and } \\
\text { Wiggins } \\
1980^{19}\end{array}$ & 3-y-old male & $\begin{array}{l}\text { Mode of exposure: ingestion } \\
\text { Amount: } 10 \mathrm{~mL} \\
\text { Child became deeply comatose } \\
\text { after } 30 \text { min of ingestion. Child } \\
\text { was recovered within } 24 \mathrm{~h} \text { of } \\
\text { ingestion. }\end{array}$ \\
\hline $\begin{array}{l}\text { Darben et al } \\
1998^{20}\end{array}$ & $\begin{array}{l}\text { 6-y-old } \\
\text { female }\end{array}$ & $\begin{array}{l}\text { Mode of exposure: topical } \\
\text { application } \\
\text { No seizures, but child had } \\
\text { encephalopathy. }\end{array}$ \\
\hline $\begin{array}{l}\text { Burkhard et al } \\
1999^{9}\end{array}$ & $\begin{array}{l}\text { Two adult } \\
\text { patients } \\
\text { One infant } \\
\text { female }\end{array}$ & $\begin{array}{l}\text { Infant was given baths } \\
\text { containing EO. } \\
\text { Child had status epilepticus. }\end{array}$ \\
\hline $\begin{array}{l}\text { Flaman et al } \\
2001^{16}\end{array}$ & $\begin{array}{l}50(20 \%) \\
\text { children were } \\
\text { exposed to } \\
\text { eucalyptus oil }\end{array}$ & $\begin{array}{l}\text { Mode of exposure: ingestion } \\
\text { Two children had seizures and } \\
\text { recovered completely. }\end{array}$ \\
\hline $\begin{array}{l}\text { Waldman } \\
2011^{18}\end{array}$ & $\begin{array}{l}\text { 4-y-old } \\
\text { female }\end{array}$ & $\begin{array}{l}\text { Mode of exposure: dermal } \\
\text { application over scalp. } \\
\text { She had seizures } 3.5 \text { h after } \\
\text { exposure. No antiepileptics } \\
\text { used. }\end{array}$ \\
\hline $\begin{array}{l}\text { Kumar et al } \\
2015^{17}\end{array}$ & $\begin{array}{l}6-y \text {-old male } \\
\text { and 3-y- } \\
\text { old male }\end{array}$ & $\begin{array}{l}\text { Mode of exposure: ingestion } \\
\text { Amount: } 5 \text { and } 10 \mathrm{~mL} \text {. } \\
\text { Both had status epilepticus } \\
10 \text { min after ingestion. }\end{array}$ \\
\hline $\begin{array}{l}\text { Mathew et al } \\
2017^{13}\end{array}$ & $\begin{array}{l}\text { Five adult } \\
\text { patients } \\
\text { Five children }\end{array}$ & $\begin{array}{l}\text { Mode of exposure: inhalation } \\
\text { (one child: massage oil, one } \\
\text { child: intranasal drops) } \\
\text { All are recovered within } 24-48 \\
\text { h. } \\
\text { Six patients used antiepileptic } \\
\text { drugs for } 2 \text { wk. }\end{array}$ \\
\hline $\begin{array}{l}\text { Kasinathan } \\
\text { and Sharawat } \\
2020^{21}\end{array}$ & 4-y-old male & $\begin{array}{l}\text { Mode of exposure: inhalation. } \\
\text { Child had seizures within } 3 \text { min } \\
\text { of inhalation. Child received } \\
\text { valproate for } 2 \mathrm{wk} \text {. }\end{array}$ \\
\hline $\begin{array}{l}\text { Sitaraman } \\
\text { and Rao } \\
2019^{22}\end{array}$ & $\begin{array}{l}\text { 17-mo-old } \\
\text { female }\end{array}$ & $\begin{array}{l}\text { Mode of exposure: ingestion } \\
\text { Amount: } 0.5 \mathrm{~mL} \\
\text { Child became drowsy for } 12 \mathrm{~h} \text {. }\end{array}$ \\
\hline
\end{tabular}

study, patients 1 and 2 had taken levetiracetam for 2 weeks duration.

The availability of limited literature, inattention of the caregivers and improper diagnosis of health care professionals, and mysterious relation between the EO ingestion and seizures are the major leading problems in the recognition of EOIS. Hence, while approaching the first episode of seizures, the clinician needs to enquire about EO ingestion along with other toxin or drug history, because preparations containing EO are available almost at every home. All three patients received the same brand of $\mathrm{EO}$, which is commonly available in their locality. Unfortunately, usage dose and precautions are missing on packaging labels in commercially available EO products in the market. Caregivers may not reveal the history, and there is also a chance that the treating clinician might ignore history, because most of the health care providers are unaware of the epileptogenic potential of EO. This might result in unnecessary expensive investigations. Simultaneously, these seizures may be falsely labeled as idiopathic seizures, and the patient could be advised for the longterm antiepileptic drugs unnecessarily. But the relationship between the EO and seizures needs to be further explored in large scale retrospective studies.

\section{Conclusion}

In conclusion, EOIS is an underrecognized and rare entity of seizures. The knowledge about EOIS is essential to be disseminated among health care professionals and the general population. We also recommend clinicians to inquire about the exposure to EO, in patients presented with first-episode of seizures or breakthrough seizures, which can prevent unnecessary investigations and long-term antiepileptic drug therapy.

\section{Authors' Contributions}

S.C.D. contributed toward data collection, literature review, and preparation of the manuscript, guarantor of the article. P.M. did the literature review and follow-up. L.K.C. conceptualized and supervised the data, critically reviewed the article.

\section{Funding \\ None.}

\section{Conflict of Interest}

None declared.

\section{References}

1 U.S. National Library of Medicine website Medline Plus. Available at: http://www.nlm. nih.gov/medlineplus/druginfo/ natural/700.html. Accessed February 20, 2020

2 Vigan M. Essential oils: renewal of interest and toxicity. Eur J Dermatol 2010;20(6):685-692

3 Spoerke DG, Vandenberg SA, Smolinske SC, Kulig K, Rumack BH. Eucalyptus oil: 14 cases of exposure. Vet Hum Toxicol 1989;31(2):166-168

4 Webb NJ, Pitt WR. Eucalyptus oil poisoning in childhood: 41 cases in south-east Queensland. J Paediatr Child Health 1993;29(5):368-371 
5 Schütte HR. Secondary plant substances. Monoterpenes. Prog Bot 1984;46:119-139

6 Dhakad AK, Pandey VV, Beg S, Rawat JM, Singh A. Biological, medicinal and toxicological significance of Eucalyptus leaf essential oil: a review. J Sci Food Agric 2018;98(3):833-848

7 Whitman BW, Ghazizadeh H. Eucalyptus oil: therapeutic and toxic aspects of pharmacology in humans and animals. J Paediatr Child Health 1994;30(2):190-191

8 Tibballs J. Clinical effects and management of eucalyptus oil ingestion in infants and young children. Med J Aust 1995; 163(4):177-180

9 Burkhard PR, BurkhardtK, Haenggeli CA, Landis T. Plant-induced seizures: reappearance of an old problem. J Neurol 1999; 246(8):667-670

10 Steinmetz MD, Vial M, Millet Y. Actions of essential oils of rosemary and certain of its constituents (eucalyptol and camphor) on the cerebral cortex of the rat in vitro. J Toxicol Clin Exp 1987;7(4):259-271

11 Culić M, Keković G, Grbić G, et al. Wavelet and fractal analysis of rat brain activity in seizures evoked by camphor essential oil and 1,8-cineole. Gen Physiol Biophys 2009;28(Spec No):33-40

12 Day LM, Ozanne-Smith J, Parsons BJ, Dobbin M, Tibballs J. Eucalyptus oil poisoning among young children: mechanisms of access and the potential for prevention. Aust N Z J Public Health 1997;21(3):297-302
13 Mathew T, Kamath V, Kumar RS, et al. Eucalyptus oil inhalationinduced seizure: a novel, underrecognized, preventable cause of acute symptomatic seizure. Epilepsia Open 2017;2(3):350-354

14 Esmonde-White HP. Eucalyptus oil poisoning. Ind Med Gaz 1898;33(3):107

15 Foggie WE. Eucalyptus oil poisoning. BMJ 1911;1(2616) 359-360

16 Flaman Z, Pellechia-Clarke S, Bailey B, McGuigan M. Unintentional exposure of young children to camphor and eucalyptus oils. Paediatr Child Health 2001;6(2):80-83

17 Kumar KJ, Sonnathi S, Anitha C, Santhoshkumar M. Eucalyptus oil poisoning. Toxicol Int 2015;22(1):170-171

18 Waldman N. Seizure caused by dermal application of overthe-counter eucalyptus oil head lice preparation. Clin Toxicol (Phila) 2011;49(8):750-751

19 Patel S, Wiggins J. Eucalyptus oil poisoning. Arch Dis Child 1980;55(5):405-406

20 Darben T, Cominos B, Lee CT. Topical eucalyptus oil poisoning. Australas J Dermatol 1998;39(4):265-267

21 Kasinathan A, Sharawat IK. Plant oil inhalation induced seizures: a less known entity. Indian J Pediatr 2020;87(5):398

22 Sitaraman R, Rao G. A pediatric case of accidental eucalyptus oil poisoning from New Delhi, India: emergency measures, historical context, and implications for practice. Cureus 2019; 11(9):e5734 